\title{
PENGARUH JENIS KEMASAN BERBEDA PADA PENYIMPANAN SUHU RUANG TERHADAP MUTU DAN DAYA SIMPAN IKAN CAKALANG (Katsuwonus pelamis) ASAP YANG DIPRODUKSI DI KOTA KENDARI
}

\author{
The Effect of Different Packaging Types on Room Temperature Storage on Quality and Storability of Cakalang Fish \\ (Katsuwonus pelamis) Smoked Produced In Kendari City \\ Fajrin Assidik*, Kobajashi Togo Isamu, Suwarjoyowirayatno \\ Jurusan Teknologi Hasil Perikanan, Fakultas Perikanan dan IImu Kelautan Universitas Halu Oleo, Kendari, \\ Sulawesi Tenggara, Indonesia \\ *Email korespondensi: fajrinhoe8@gmail.com (Telp: +6282271365028) \\ Diterima: 5 September/ Disetujui 30 Oktober 2020
}

Cara sitasi: Assidik F, Isamu KT, Suwarjoyowirayatno. 2020. Pengaruh jenis kemasan berbeda pada penyimpanan suhu ruang terhadap mutu dan daya simpan ikan cakalang (Katsuwonus pelamis) asap yang diproduksi di Kota Kendari. Jurnal Fish Protech. 3(2):214-223.

\begin{abstract}
The aims of this study was to determine the effect of different types of packaging on room temperature storage on organoleptic values, chemical test values, and the total number bacteria of smoked skipjack tuna produced in Kendari City. The parameters tested were organoleptic test, water content, fat content, phenol, and total plate count (TPC) of smoked skipjack tuna. This study used a non-factorial Completely Randomized Design (CRD) consisting of two treatments, namely $P P$ (polyethylene packaging) and PE (polypropylene packaging). Each treatment was carried out 3 times of observation for 2 days in order to obtain the number of experimental units as many as 18 units. The data obtained were analyzed using analysis of variance (ANOVA), if the results of the analysis showed a significant difference, the Duncan's Multiple Range Test (DMRT) was carried out to determine the real difference between treatments with a confidence level of $95 \%$ ( $\alpha=$ 0.05). The results obtained showed that the type of packaging technique and storage time of smoked skipjack tuna had a very significant effect on the organoleptic value of the aroma, while the appearance and texture had a significant effect, and the mucus showed a significant effect. The best results for organoleptic assessment were found in the PPO treatment which had appearance values of 7.23, flavour 7.30, texture 7.40 and mucus 9.00 . The best treatment in the chemical test was in the PP2 treatment with a water content value of $58.6 \%$, a fat content value of $4.1 \%$, and a phenol content value of $583.317 \mathrm{mg} / 100 \mathrm{~g}$ while the total bacteria count (TPC) value showed the best value, namely the PPO treatment with a value of $1,66 \times 10^{4} \mathrm{CFU} / \mathrm{ml}$.
\end{abstract}

Keywords: smoked skipjack tuna (Katsuwonus pelamis), smoking, packaging, storage, room temperature.

\begin{abstract}
ABSTRAK
Tujuan dari penelitian ini adalah untuk mengetahui pengaruh jenis kemasan berbeda pada penyimpanan suhu ruang terhadap nilai organoleptik, nilai uji kimia, dan jumlah total bakteri ikan cakalang asap yang diproduksi di Kota Kendari. Parameter yang diuji yaitu uji organoleptik, uji kadar air, uji kadar lemak, ujikadar fenol, dan jumlah total bakteri (TPC) ikan cakalang asap. Penelitian ini menggunakan Rancanagan Acak Lengkap (RAL) faktorial yang terdiri dari dua perlakuan yaitu PP (kemasan polyethylene) dan PE (kemasan polypropylene). Masing-masing perlakuan dilakukan 3 kali pengamatan selama 2 hari sehingga diperoleh jumlah satuan percobaan sebanyak 18 unit. Data yang diperoleh dianalisis menggunakan analisis ragam (ANOVA), jika hasil analisis menunjukan beda nyata maka dilakukan uji Duncan's Multiple Range Test (DMRT) untuk mengetahui beda nyata antar perlakuan dengan tingkat kepercayaan $95 \%(\alpha=0,05)$. Hasil penelitian yang diperoleh menunjukkan bahwa teknik jenis kemasan dan waktu penyimpanan ikan cakalang asap memberikan pengaruh sangat nyata terhadap nilai organoleptik aroma, sedangkan kenampakan dan tekstur menunjukkan hasil yang berpengaruh nyata, dan lendir menunjukkan hasil berpengaruh nyata. Hasil terbaik untuk penilaian organoleptik terdapat pada perlakuan PP0 dimana memiliki nilai kenampakan 7,23, aroma 7,30, tekstur 7,40 dan lendir 9,00 . Perlakuan terbaik pada uji kimia terdapat pada perlakuan PP2 dengan nilai kadar air 58,6\%, nilai kadar lemak 4,1\%, dan nilai kadar
\end{abstract}

http://ojs.uho.ac.id/index.php/jfp 
fenol $583,317 \mathrm{mg} / 100 \mathrm{~g}$ sedangkan nilai jumlah total bakteri (TPC) menunjukkan nilai terbaik yaitu perlakuan PP0 dengan nilai $1,66 \times 10^{4} \mathrm{CFU} / \mathrm{ml}$.

Kata kunci: : ikan cakalang asap (Katsuwonus pelamis), pengasapan, pengemasan, penyimpanan, suhu ruang.

\section{PENDAHULUAN}

Potensi pengembangan sumber daya perikanan di Provinsi Sulawesi Tenggara sangat strategis untuk dikembangkan karena didukung oleh faktor yaitu letak geografis kota Kendari sebagai ibu kota dari provinsi Sulawesi Tenggara yang berdekatan dengan Laut Banda yang dikenal memiliki ikan cakalang yang melimpah (Isamu et al, 2012). Menurut KKP (2019) tuna, cakalang, dan tongkol (TCT) merupakan komoditas dengan nilai ekspor kedua setelah udang. Tahun 2018, tuna, TCT menyumbang devisa sebesar 713,9 juta USD atau $14,69 \%$ dari total nilai ekspor hasil perikanan. Volume pada tahun 2018 ekspor TCT Indonesia sebesar 168,4 ribu ton atau $14,96 \%$ dari total volume ekspor hasil perikanan.

Ikan cakalang merupakan salah satu komoditi yang memiliki prospek ekonomi yang cukup tinggi. Ikan cakalang hampir terdapat di seluruh perairan Indonesia terutama di Indonesia bagian Timur. Spesies ikan ini digunakan sebagai bahan baku berbagai jenis industri pengolahan seperti ikan asap, ikan fufu, ikan kayu, ikan kaleng, abon cakalang dan lain sebagainnya (Lumi, 2013). Ikan cakalang memiliki kelemahan yaitu mudah mengalami pembusukan setelah ditangkap. Untuk itu diperlukan teknik pengolahan untuk meningkatkan daya simpannya (Nabila et al., 2017).

Upaya untuk menghambat proses pembusukan dengan cara pengawetan dan pengolahan salah satunya yaitu pengasapan. Pengasapan adalah salah satu cara pengolahan ikan yang berfungsi untuk mengawetkan serta memberi aroma dengan cita rasa yang khas (Patty et al., 2015). Pengasapan merupakan suatu cara pengolahan atau pengawetan dengan memanfaatkan kombinasi perlakuan pengeringan dan pemberian senyawa kimia dari hasil pembakaran bahan bakar alami (Wibowo, 2000).
Kemasan merupakan salah satu cara atau metode untuk memberikan perlindungan pada pangan yang telah dihasilkan baik dalam bentuk bungkusan atau menempatkan produk ke dalam suatu wadah (Hidayat, 2018). Menurut Furqon et al. (2016) jenis plastik polyethelene (PE) dan Polypropylene (PP) memiliki kerapatan yang tinggi, tahan terhadap suhu dan kelembapan, serta memiliki daya serap air yang rendah sehingga mampu melindungi produk. Selain itu, plastik memiliki keunikan dalam penampilan fisik yaitu sifatnya yang sangat elastis, memiliki warna yang transparan sehingga produk akan terlihat dari luar kemasan. Berdasarkan kelebihan tersebut pemilihan pengemas plastik menjadi faktor yang sangat penting untuk melindungi mutu produk.

Hasil penelitian Shabrina et al. (2014) proses pengasapan ikan bandeng menggunakan kombinasi $\mathrm{K} 1$ : tungku $40 \mathrm{~cm}$, suhu $60-70^{\circ} \mathrm{C}$ lama pengasapan 3 jam. K2 : tungku $60 \mathrm{~cm}$, suhu $40-50^{\circ} \mathrm{C}$, lama pengasapan 6 jam. beserta lama penyimpanan memberikan pengaruh secara nyata terhadap kemunduran mutu ikan bandeng asap dengan nilai parameter : organoleptik, TBA, TVBN, TPC, pH, kadar air dan fenol $(P<0,05)$. Sementara Nanlohy $(2014)$ melakukan penyimpanan ikan tuna asap yang direndam dengan asap cair "waa sagu" pada suhu kamar menghasilkan nilai TPC 5,0 × $10^{1} \mathrm{cfu} / \mathrm{g}$ pada hari ke-0 dan $9,0 \times 10^{2} \mathrm{cfu} / \mathrm{g}$ pada hari ke-10 pada produk sudah melebihi SNI $\left(1,0 \times 10^{5}\right)$.

Berdasarkan hal tersebut sehingga mendasari penelitian tentang pengaruh jenis kemasan berbeda pada penyimpanan suhu ruang terhadap mutu dan daya simpan ikan cakalang (Katsuwonus pelamis) asap yang diproduksi di Kota Kendari. 


\section{METODE PENELITIAN}

\section{Alat dan Bahan}

Alat yang digunakan pada penelitian ini yaitu alat yang digunakan meliputi penghitung koloni "hand totally counter", bunsen, botol media, gunting, pinset, autoclave, refrigerator, freezer, tabung soxhlet, oven listrik (Memmert), cawan alumunium, gegep, timbangan analitik, labu kjeldahl $300 \mathrm{~mL}$, buret skala $0,1 \mathrm{~mL}$, pipet tetes, pipet mikro, dan seperangkat alat spektrofotometer UV-Vis. @Rayleigh 7200.

Bahan yang digunakan terdiri atas bahan utama dan bahan pendukung. Bahan utama adalah ikan cakalang asap. Bahan pendukung adalah bahan pengemasan menggunakan kemasan polypropylene (PP) dan kemasan polyethylene (PE). Bahan yang digunakan meliputi Plate Count Agar, alkohol 70\%, kapas, kertas saring, Potassium Dihydrogen Phosphate, Butterfield's Phosphate Buffered, Nhexan, $\mathrm{NaOH}$, aquades, reagan Folin-Ciocalteu dan $\mathrm{Na}_{2} \mathrm{CO}_{3} 10 \%$.

\section{Rancangan Penelitian}

Penelitian ini menggunakan Rancanagan Acak Lengkap (RAL) faktorial yang terdiri dari dua perlakuan yaitu PP (kemasan polyethylene) dan PE (kemasan polypropylene). Masing-masing perlakuan dilakukan 3 kali pengamatan selama 2 hari sehingga diperoleh jumlah satuan percobaan sebanyak 18 unit.

\section{Penyediaan Bahan Baku}

Sampel ikan cakalang asap diperoleh dari produsen pengasapan di Pasar Anduonohu Kota Kendari, Sulawesi Tenggara. Pengambilan sampel ikan cakalang asap ditimbang $\pm 800 \mathrm{gr} / \mathrm{ekor}$ dan sampel dimasukkan kedalam wadah plastik. Bahan pengemasan diperoleh dari toko yang menyediakan kemasan polypropylene dan polyethylene.

\section{Proses Pengemasan}

Proses pengemasan yang terdiri dari 2 jenis kemasan yang berbeda yaitu kemasan Polyethylene (PP) dan kemasan polypropylene (PE) dan kemudian dilakukan proses penyimpanan di suhu ruang yaitu 0 hari, 1 hari, dan 2 hari yang terdiri dari 3 ulangan .

\section{Variabel Pengamatan}

Variabel pengamatan yang akan diuji pada penelitian ini adalah uji organoleptik (BSN, 2013), analisis kadar air (AOAC, 2005), analisis kadar lemak (AOAC, 2005), analisis kadar fenol dengan metoda Folin-Ciocalteu (Orak, 2006) dan analisis total bakteri (TPC) (Hadiwiyoto, 1994).

\section{Analisis Data}

Data yang diperoleh dianalisis menggunakan analisis ragam (ANOVA), jika hasil analisis menunjukan beda nyata maka dilakukan uji Duncan's Multiple Range Test (DMRT) untuk mengetahui beda nyata antar perlakuan dengan tingkat kepercayaan $95 \%(\alpha=0,05)$.

\section{Uji Organoleptik}

\section{HASIL DAN PEMBAHASAN}

Berdasarkan uji organoleptik terhadap parameter kenampakan, aroma, tekstur, dan lendir ikan cakalang asap yang dikemas polypropylene dan polyethylene pada penyimpanan 0, 1 dan 2 hari pada suhu ruang. Berikut Rerata nilai uji organoleptik disajikan pada Tabel 1 dibawah ini.

Tabel 1. Nilai uji organoleptik ikan cakalang asap

\begin{tabular}{ccccc}
\hline \multirow{2}{*}{ Perlakuan } & \multicolumn{4}{c}{ Parameter } \\
\cline { 2 - 5 } & Kenampakan & Aroma & Tekstur & Lendir \\
\hline PP0 & $7,23^{\mathrm{c}} \pm 0.59$ & $7,30^{\mathrm{d}} \pm 0,26$ & $7,40^{\mathrm{c}} \pm 0,26$ & $9,00^{\mathrm{b}} \pm 0,00$ \\
PP1 & $5,90^{\mathrm{ab}} \pm 0.72$ & $5,37^{\mathrm{b}} \pm 0,61$ & $6,67^{\mathrm{bc}} \pm 0,46$ & $6,65^{\mathrm{a}} \pm 0,73$ \\
PP2 & $5,17^{\mathrm{a}} \pm 0,42$ & $6,97^{\mathrm{d}} \pm 0,31$ & $5,60^{\mathrm{a}} \pm 0,75$ & $7,27^{\mathrm{a}} \pm 0,61$ \\
PE0 & $6,60^{\mathrm{bc}} \pm 0.50$ & $6,97^{\mathrm{d}} \pm 0,31$ & $7,53^{\mathrm{c}} \pm 0,25$ & $8,87^{\mathrm{b}} \pm 0,23$ \\
PE1 & $5,67^{\mathrm{ab}} \pm 0.51$ & $5,93^{\mathrm{c}} \pm 0,12$ & $6,83^{\mathrm{bc}} \pm 0,45$ & $7,27^{\mathrm{a}} \pm 0,46$ \\
PE2 & $6,00^{\mathrm{ab}} \pm 0.62$ & $4,17^{\mathrm{a}} \pm 0,12$ & $5,97^{\mathrm{ab}} \pm 0,59$ & $6,47^{\mathrm{a}} \pm 0,83$ \\
\hline
\end{tabular}

http://ojs.uho.ac.id/index.php/jfp 
Keterangan: $\mathrm{PP0}=$ Polypropylene $(0$ hari $), \mathrm{PP} 1=$ Polypropylene $(1$ hari $), \mathrm{PP} 2=$ Polypropylene $(2$ hari $)$, $\mathrm{PE} 0=$ Polyethylene $(0$ hari), $\mathrm{PE} 1=$ Polyethylene $(1$ hari $), \mathrm{PE} 2=$ Polyethylene $(2$ hari $)$.

\section{Kenampakan}

Data pada Tabel 1, ikan cakalang asap yang dikemas polypropylene dan polyethelene selama penyimpanan terjadi penurunan nilai organoleptik kenampakannya hal ini kemungkinan disebabkan karena selama penyimpanan akan terjadi perubahanperubahan pada daging ikan cakalang asap oleh adanya reaksi enzim dan adanya aktivitas mikroba sehingga tidak disukai oleh panelis.

Penurunan parameter kenampakan paling cepat terjadi pada perlakuan kemasan polyethylene hal ini disebabkan kemasan polyethylene memiliki permeabilitas yang tinggi dibandingkan kemasan polypropylene sehingga udara masuk kedalam kemasan polyethylene lebih cepat, maka dapat memicu naiknya kadar air dan dapat mempermudah pertumbuhan bakteri lebih cepat

Winarno (2002) menyatakan bahwa penurunan kenampakan dikarenakan aktivitas bakteri, sedangkan perlakuan menggunakan kemasan polypropylene mampu memperlambat penurunan parameter kenampakan dikarenakan udara yang masuk kedalam kemasan polypropylene lambat maka pertumbuhan bakteri akan melambat dan menurut Moeljianto (1992) menyatakan bahwa warna ideal dari ikan hasil proses pengasapan adalah warna kuning emas kecoklatan.

Hasil penelitian Husen dan Daeng (2018) mendapatkan tingkat penerimaan terhadap penampakan daging cakalang asap nilai dengan ratarata dengan lama penyimpanan 0 hari yaitu 5,24 dan menurut Winarno (2009) menyatakan bahwa nilai rupa lebih banyak melibatkan indra penglihatan dan merupakan salah satu indikator untuk menentukan bahan pangan diterima atau tidak oleh konsumen, karena makanan yang berkualitas (rasa enak, bergizi, dan tekstur baik) belum tentu disukai oleh konsumen bila rupa bahan pangan tersebut memiliki rupa yang tidak enak dipandang konsumen.

\section{Aroma}

Data pada Tabel 1, ikan cakalang asap yang dikemas polypropylene dan polyethelene serta lama penyimpanan terjadi penurunan nilai organoleptik aromanya hal ini kemungkinan disebabkan timbulnya jamur pada ikan sehingga ikan mulai berbau tengik dan menurut Widiastuti (2007) menyatakan kehadiran mikroorganisme pada ikan juga mengakibatkan perubahan bau. Bau tersebut timbul akibat timbulnya amoniak $\left(\mathrm{NH}_{3}\right)$ pada degradasi protein dan gas $\mathrm{H}_{2} \mathrm{~S}$ pada degradasi protein yang mengandung unsur sulfur oleh bakteri pembentuk gas $\mathrm{H}_{2} \mathrm{~S}$.

Penurunan parameter aroma paling cepat terjadi pada perlakuan kemasan polyethylene hal ini disebabkan kemasan polyethylene memiliki permeabilitas yang tinggi dibandingkan kemasan polypropylene sehingga udara masuk kedalam kemasan polyethylene lebih cepat, maka dapat memicu naiknya kadar air dan dapat mempermudah pertumbuhan bakteri selain itu juga terjadi perubahan aroma menjadi beraroma amoniak dan tengik dan menurut Rahayu et al. (1992) menyatakan bahwa penyimpangan aroma yang terjadi pada produk perikanan disebabkan oleh adanya enzim dan mikroorganisme. Bau busuk terjadi akibat aktivitas bakteri proteolitik sedangkan bau tengik disebabkan oleh enzim lipolitik dan oksigen.

Hasil penelitian Husen dan Daeng (2018) mendapatkan tingkat penerimaan terhadap tekstur daging cakalang asap nilai dengan rata-rata dengan lama penyimpanan 0 hari yaitu 4,60 dengan demikian bahwa aroma danging ikan cakalang asap memiliki aroma yang baik untuk konsumen dan menurut Soekarno (1990) menyatakan bahwa aroma/bau merupakan salah satu parameneter enaknya suatau makanan.

\section{Tekstur}

Data pada Tabel 1, ikan cakalang asap yang dikemas polypropylene dan polyethelene serta lama penyimpanan terjadi penurunan nilai organoleptik teksturnya hal ini kemungkinan disebabkan oleh kadar air yang mengalami perubahan selama penyimpanan dan selain pengaruh kadar air menurut Tribowo (1985) aksi bakterial maupun enzim mengakibatkan 
degradasi jaringan pengikat yang menyebabkan penurunan nilai tekstur sehingga menjadi lunak

Penurunan parameter tekstur yang terjadi pada perlakuan kemasan polypropylene dan kemasan polyethylene disebabkan adanya udara dalam kemasan, maka dapat memicu naiknya kadar air dan menurut Purnomo (1995) kadar air yang tinggi menyebabkan tekstur pada bahan pangan menjadi lunak. Tingginya kadar air juga dapat mempermudah pertumbuhan mikrooganisme serta menurut Widiastuti (2007) menyatakan kehadiran mikroganisme pada ikan mengakibatkan perubahan tekstur.

Hasil penelitian Husen dan Daeng (2018) mendapatkan tingkat penerimaan terhadap tekstur daging cakalang asap nilai dengan rata-rata dengan lama penyimpanan 0 hari yaitu 5,08 dengan demikian tekstur ikan cakalang asap dikategorikan segar karena memiliki tekstur yang padat dan kenyal dan menurut Berhimpon (1993) bahwa perubahan tekstur dimana daging menjadi lebih lunak terjadi apabila ikan sudah mulai mengalami kemunduran mutu. $\mathrm{Hal}$ ini disebabkan mulai terjadinya perombakan pada jaringan otot daging oleh proses enzimatis.

\section{Lendir}

Data pada Tabel 1, ikan cakalang asap yang dikemas polypropylene dan polyethelene serta lama penyimpanan terjadi penurunan nilai organoleptik lendirnya hal ini kemungkinan disebabkan terdapatnya lendir pada ikan tampak masih mengkilap tetapi sudah mulai kurang cerah yang menandakan ikan sudah kurang segar selama penyimpanan.

Penurunan parameter lendir paling cepat terjadi pada perlakuan kemasan polyethylene karena disebabakan perkembang biakan bakterinya lebih cepat dibandingkan kemasan polypropylene dan menurut Lindsay (1994) bahwa lendir yang timbul pada ikan asap disebabkan oleh proses perkembangan bakteri pada kulit dan daging ikan.

\section{Uji Kimia}

Pengukuran uji kimia pada setiap bahan pangan sangat penting karena tinggi rendahnya kandungan kimia dalam bahan pangan akan menentukan mutu akhir dari suatu produk. Berikut hasil uji kimia ikan cakalang asap yang dikemas polypropylene dan polyethylene pada penyimpanan 0 , 1 dan 2 hari pada suhu ruang disajikan pada Tabel 2. dibawah ini.

Tabel 2. Hasil analisis terhadap nilai uji kimia ikan cakalang asap

\begin{tabular}{llll}
\hline \multirow{2}{*}{ No } & \multirow{2}{*}{$\begin{array}{l}\text { Kode } \\
\text { Sampel }\end{array}$} & \multicolumn{2}{l}{ Parameter } \\
\cline { 3 - 4 } & & $\begin{array}{l}\text { Kadar } \\
\text { air }(\%)\end{array}$ & $\begin{array}{l}\text { Kadar } \\
\text { lemak (\%) }\end{array}$ \\
\hline 1 & PP0 & 61,0 & 5,2 \\
2 & PP1 & 59,0 & 5,5 \\
3 & PP2 & 58,6 & 4,1 \\
4 & PE0 & 60,0 & 4,6 \\
5 & PE1 & 57,6 & 4,8 \\
6 & PE2 & 58,4 & 7,3 \\
\hline
\end{tabular}

Keterangan: $\mathrm{PP0}=$ Polypropylene $(0$ hari), $\mathrm{PP} 1=$ Polypropylene $(1$ hari), PP2 $=$ Polypropylene $(2$ hari $), \mathrm{PE} 0=$ Polyethylene $(0$ hari), $P E 1=$ Polyethylene (1 hari), PE2 $=$ Polyethylene $(2$ hari).

\section{Kadar Air}

Hasil penelitian pada Tabel 2, terlihat bahwa semakin lama masa simpan suatu produk baik untuk ikan cakalang asap yang dikemas polypropylene maupun polyethylene maka nilai kadar air ikan cakalang asap tersebut akan semakin menurun. Penurunan ini dapat disebabkan karena adanya pemanasan terhadap produk sehingga terjadi penguapan air di dalam dan di luar produk

Kemasan polypropylene mengalami penurunan konstan dari penyimpanan 0 hari hingga penyimpanan 2 hari sedangkan kemasan polyethylene mengalami perubahan kadar air yang semula mengalami penurunan pada penyimpanan 1 hari mengalami kenaikan pada penyimpanan 2 hari diduga karena plastik jenis polypropylene lebih sukar dilewati gas ataupun uap air dari pada jenis polyethylene.

Menurut Leha (2010) kadar air bervariasi selama penyimpanan yang cenderung meningkat, kenaikan kadar air ini disebabkan karena kondisi lingkungan penyimpanan mempunyai kelembaban tinggi, sehingga kadar air ikan asap dipengaruhi oleh kelembaban udara sekitarnya. Bila kadar air bahan lebih kecil dibanding kelembaban disekitarnya maka 
akan terjadi penyerapan air ke dalam bahan produk sehingga kadar airnya menjadi lebih tinggi.

Perbedaan ini diduga karena kemasan polypropylene lebih baik dalam mempertahankan kadar air ikan cakalang asap karena memiliki permeabilitas uap air yang rendah dari pada polyethylene. Hal ini sesuai yang dikemukan oleh Mareta dan Sofia (2011) bahwa permeabilitas plastik polypropylene lebih kecil dibandingkan plastik polyethylene sehingga uap air akan lebih sulit menembus plastik polypropylene dari pada polyethylene serta Suyitno (1990) menyatakan bahwa kemasan polypropylene memiliki sifat yang lebih keras dengan titik lunak yang lebih tinggi dibandingkan polyethylene.

Hasil penelitian Tumondo et al. (2017) tentang nilai kadar air ikan cakalang asap selama penyimpanan memperoleh nilai kadar air 51,67 pada penyimpanan 0 hari, $62,16 \%$ pada penyimpanan 1 hari, dan 63,60\% pada penyimpanan 2 hari, sedangkan hasil penelitian Wally et al. (2015) menunjukkan bahwa kadar air ikan cakalang asap pada penyimpanan 0 hari yaitu $62,5 \%$, penyimpanan 2 hari yaitu $62, \%$ dan penyimpanan 4 hari yaitu $63,6 \%$ dan hasil penelitian Isamu et al. (2012) yaitu kadar air ikan cakalang asap yang diproduksi di kota Kendari berkisar $64,13 \%-67,14 \%$ seta hasil penelitian Hadinoto et al. (2015) yaitu kadar air ikan cakalang asap berkisar $59,00 \%$.

Keawetan bahan pangan mempunyai hubungan yang erat dengan kadar air. Semakin rendah kadar air dalam bahan pangan diharapkan dapat memperpanjang masa simpannya. Menurut Esminingtyas (2006), kandungan air dalam bahan makanan mempengaruhi daya tahan bahan makanan terhadap serangan mikroba.

\section{Lemak}

Hasil penelitian pada Tabel 2, persentase kadar lemak pada ikan cakalang asap pada kemasan polypropylene mengalami penurunan selama penyimpanan sedangkan kemasan polyethylene mengalami kenaikan. Presentase kadar lemak pada kemasan polypropylene berbanding lurus dengan kadar air. Hal ini sesuai dengan pernyataan
Swastawati et al. (2012) kadar lemak menurun seiring terjadi pengurangan kadar air, karena sebagian lemak dalam tubuh ikan ikut mengalami driploss. Dibandingkan presentase kadar lemak pada kemasan polyethylene berbanding terbalik dengan kadar air. Hal ini sesuai dengan pernyataan Rahayu et al. (1992) menyatakan bahwa kadar lemak ikan berbanding terbalik dengan kadar air, sedangkan menurut Riansyah et al. (2013) bahwa ikan dengan kandungan lemak yang tinggi biasanya mempunyai kandungan air cenderung lebih rendah dan menurut Isamu et al. (2012) menyatakan berkurangnya kadar air produk dapat menyebabkan komponen protein, lemak dan abu menjadi meningkat, hal ini diduga masih terikat dalam air, dengan hasil penelitiannya kadar lemak ikan cakalang asap yang diproduksi di Kendari berkisar 1,75\%-3,40\% dan hasil penelitian Salindeho (2017) menunjukkan bahwa kadar lemak ikan cakalang asap berkisar antara 2,69\%-2,87\%.

Menurut Winarno (1986) bahwa pemanasan pada suhu tinggi akan mempercepat gerakan-gerakan molekul lemak sehingga jarak antara molekul menjadi besar, dengan demikian akan memudahkan pengeluaran lemak dari bahan, sedangkan menurut Hadjinikolova (2008) menyatakan proses pengolahan dengan menggunakan prinsip pemanasan seperti pengeringan, pengukusan dan pengasapan akan menyebabkan sebagian lemak meleleh keluar dari bagian-bagian daging ikan tetapi pengukuran kandungan lemak juga akan dipengaruhi oleh kandungan air yang terukur.

\section{Uji Fenol}

Penelitian ini dilakukan uji fenol untuk mengetahui kandungan fenol ikan cakalang asap yang dikemas polypropylene dan polyethylene pada penyimpanan 0, 1 dan 2 hari pada suhu ruang. Berikut hasil nilai uji fenol disajikan pada Tabel 3. 
Tabel 3. Hasil analisis terhadap nilai uji fenol ikan cakalang asap

\begin{tabular}{llll}
\hline No & $\begin{array}{l}\text { Kode } \\
\text { Sampel }\end{array}$ & $\begin{array}{l}\text { Hasil uji } \\
(\mathrm{mg} / \mathrm{kg})\end{array}$ & $\begin{array}{l}\text { Standar nilai } \\
\text { fenol }(\mathrm{mg} / \mathrm{kg})\end{array}$ \\
\hline 1 & PP0 & 8681,49 & \\
2 & PP1 & 7815,50 & \\
3 & PP2 & 5833,17 & $0,06-5000$ \\
4 & PE0 & 8161,88 & \\
5 & PE1 & 7269,17 & \\
6 & PE2 & 5379,17 &
\end{tabular}

Keterangan: PP0 $=$ Polypropylene $(0$ hari $)$, PP1 $=$ Polypropylene

Menurut Girrard (1992) menyatakan bahwa jumlah batas aman kadar fenol dalam produk pengasapan berkisar dari $0,06 \mathrm{mg} / \mathrm{kg}$ sampai 5000 $\mathrm{mg} / \mathrm{kg}$ atau 0,0006-0,5\%, sedangkan menurut Davidson dan Branen (1981) menyatakan bahwa batas aman kadar fenol pada ikan cakalang asap selama penyimpanan untuk dikonsumsi yaitu $0,02-$ $1,00 \%$.

Data pada Tabel 3, nilai kadar fenol pada ikan cakalang asap pada kemasan polypropylene maupun kemasan polyethylene mengalami penurunan selama penyimpanan pada suhu ruang namun nilai kadar fenlo kemasan polypropylene lebih tinggi daripada kemasan polyethylene dikarenakan nilai TPC pada kemasan polypropylene lebih sedikit dibandingkan kemasan polyethylene sehingga pengurangan nilai kadar fenol pada kemasan polypropylene lebih lambat dibandingkan kemasan polyethylene.

Menurut Sagoo et al. (2002) kondisi penyimpanan pada suhu ruang produk bahan pangan akan mempengaruhi jenis bakteri yang mungkin berkembang dan menyebabkan kerusakan dan dapat mempercepat proses pembusukan. Hal ini disebabkan bakteri yang terdapat pada ikan dapat melakukan metabolisme secara sempurna. Karena aktivitas anti mikrobanya, senyawa fenol dapat menghambat pertumbuhan berbagai mikroorganisme seperti bakteri, jamur, dan ragi.

Berdasarkan hasil penelitian Wowiling et al. (2020) parameter fenol pada asap mendapatkan hasil total fenol 1,31 mg/1 untuk ikan cakalang presto asap cair dengan konsentrasi 0,8\% dan 1,53 mg/1 untuk asap cair dengan konsentrasi 1,2\% dan hasil penelitian Marasabessy (2007) yaitu pada tempurung kelapa yang menghasilkan kadar fenol asap cair antara 0,6-2,76 mg/1.

\section{Uji TPC (Total Plate Count)}

penelitian ini juga dilakukan uji TPC (Total Plate Count) sebagai parameter kebusukan untuk melihat tingkat kemunduran mutu produk yang disajikan pada Tabel 4.

Tabel 4. Hasil analisis terhadap nilai uji Total Plate count (TPC) ikan cakalang asap

\begin{tabular}{llll}
\hline No & $\begin{array}{l}\text { Kode } \\
\text { Sampel }\end{array}$ & $\begin{array}{l}\text { Hasil uji } \\
(\text { CFU/g) }\end{array}$ & $\begin{array}{l}\text { Standar SNI } \\
2725(\text { CFU/g) }\end{array}$ \\
\hline 1 & PP0 & $1,66 \times 10^{4}$ & \\
2 & PP1 & $2,73 \times 10^{4}$ & \\
3 & PP2 & $3,20 \times 10^{4}$ & $5,0 \times 10^{4}$ \\
4 & PE0 & $1,72 \times 10^{4}$ & \\
5 & PE1 & $2,81 \times 10^{4}$ & \\
6 & PE2 & $3,36 \times 10^{4}$ & \\
\hline
\end{tabular}

Keterangan: $\mathrm{PP0}=$ Polypropylene $(0$ hari $), \mathrm{PP} 1=$ Polypropylene (1 hari), PP2 = Polypropylene (2 hari), PE0 $=$ Polyethylene $(0$ hari), $\mathrm{PE} 1=$ Polyethylene $(1$ hari $), \mathrm{PE} 2=$ Polyethylene (2 hari).

Data pada Tabel 4, tingginya nilai TPC pada kemasan polyethylene dibandingkan kemasan polyrpopylene diduga karena penetrasi daya gas dan uap air dari masing-masingkemasan. polyethylene memiliki permeabilitas uap air yang rendah dibandingkan kemasan polyethylene. Gas oksigen dan uap air dibutuhkan oleh bakteri untuk tumbuh dan berkembang, sehingga bakteri pada kemasan polyethylene dapat tumbuh dan berkembang lebih cepat dibanding kemasan polyrpopylene.

Menurut llyas (1983) pertumbuhan bakteri pada ikan sangat dipengaruhi oleh suhu, semakin rendahnya suhu ikan semakin lambat pertumbuhan bakteri, sedangkan menurut Buckle et al. (1985) bahwa pada tahap awal pertumbuhan mikroorganisme belum terjadi pembelahan sel. Selanjutnya setelah mampu beradaptasi dengan lingkungannya yang baru, 
sel-sel bakteri akan tumbuh dan membelah secara eksponsil sampai jumlah yang maksimun.

Menurut Angela et al. (2015) kurang tersedianya oksigen untuk kebutuhan metabolisme dari bakteri, sehingga bakteri sulit untuk berkembang biak walaupun kadar air yang dikandung produk cukup untuk aktifitas bakteri. Ketersediaan oksigen juga membatasi pertumbuhan mikroba akan terhambat, dengan hasil penelitiannya menunjukkan nilai TPC ikan cakalang asap pada penyimpanan dingin yang dikemas vakum yaitu $2,5 \times 10^{2}$ dan non vakum yaitu $4,43 \times 10^{3}$ pada penyimpanan 0 hari. Ikan cakalang asap seperti halnya produk perikanan lainnya

\section{KESIMPULAN}

Berdasarkan hasil penelitian dan

pembahasan, maka dapat disimpulkan sebagai berikut:

1. Terdapat pengaruh faktor pengemasan polypropylene dan polyethylene selama waktu penyimpaan pada suhu ruang terhadap uji organoleptik ikan cakalang asap yaitu meliputi merupakan media yang baik untuk pertumbuhan bakteri.

Menurut Saparinto (2010) ikan merupakan bahan pangan yang sangat mudah rusak dan produk makanan laut yang selalu dihubungkan dengan cemaran mikroba, sedangkan menurut Hadiwiyoto (1993) bahwa cepat lambatnya kerusakan hasil perikanan secara mikrobiologis tergantung pada kecepatan pertumbuhan mikrobia yang ada terutama bakteri pembusuk. Pertumbuhan bakteri pada umumnya diartikan sebagai kenaikan jumlah konstituen dalam sel atau massanya, kemudian diikuti oleh perbanyakan sel sehingga jumlah sel menjadi bertambah banyak.

aroma menunjukkan hasil yang berpengaruh sangat nyata, sedangkan kenampakan dan tekstur menunjukkan hasil yang berpengaruh nyata, dan lendir menunjukkah hasil berpengaruh.

2. Terdapat pengaruh faktor pengemasan polypropylene dan polyethylene selama waktu penyimpaan suhu ruang terhadap uji kadar air, kadar lemak, kadar fenol, dan TPC ikan cakalang asap.

\section{DAFTAR PUSTAKA}

AOAC. 2005. Official Methods Of Analysis. Association of Official Analytical Chemists. Benjamin Franklin Station, Washington.

Angela GC, Mentang F, dan Sanger G. 2015. Kajian Mutu Ikan Cakalang (Katsuwonus pelamis, L.) Asap dari Tempat Pengasapan Desa Girian Atas Yang Dikema Vakum dan Non Vakum Selaama penyimpanan dingin. Jurnal Media Teknologi Hasil Perikanan. 3(2). Hal: 29-40.

Buckle KA, Edwards RA, Fleet GH, dan Wootton M. 1985. IImu Pangan. Terjemahan oleh $\mathrm{H}$. Purnomo dan Adiono. Ul. Jakarta.

Esmingtiyas, R. 2006. Perubahan Mutu Ikan Lele Dumbo (Clarias gariepinus) Asap Selama Penyimpanan. Fakultas Perikanan dan Kelautan.IPB. Bogor.

Furqon A.A.Q, Maflahah I, dan Rahman A. 2016. Pengaruh Jenis Pengemas dan Lama
Penyimpanan Terhadap Mutu Produk Nugget Gembus. AGROINTEK. 10(2). Hal: 70-75.

Girrard, J.P. 1992. Technology of Meat and Meat Products. Ellis Horwood. New York.

Hadinoto S, Kolanus J.P. M., dan Manduapessy K.R.W. 2015. Karakteristik Mutu Ikan Cakalang (Katsuwonus Pelamis) Asap Menggunakan Asap Cair Dari Tempurung Kelapa. Majalah BIAM. 12(01). Hal; 20-26

Hadiwiyoto, S. 1994. Teknologi Pengolahan Hasil Perikanan. Penerbit Liberty, Yogyakarta. Hadjinikolova, L. 2008. Investigations on the Chemical Composition of Carp (Cyprinus carpio L), Bighead Carp (Aristichthys nobilis Rich) and Pike (Esox lusius $\mathrm{L}$ ) during Different Stages of Individual Growth. Bulgarian Journal of Agricultural Science. 14: 121-126.

Hidayat R. 2018. Pengaruh Jenis Kemasan Berbeda 
Terhadap Mutu Fish Chips Baby ikan Mas (Cyprinus Carpio) Selama Penyimpanan Suhu Ruang. Skripsi. Universitas Riau. Pekan Baru.

Husen A dan Raden RA. 2018. Pengaruh Lama Penyimpanan Terhadap Mutu Ikan Cakalang Asap (Katsuwonus pelamis). Jurnal Agribisnis Perikanan (11) 2, Hal: 59-64.

llyas S. 1983. Teknologi Refrigerasi Hasil Perikanan. Jilid 1. Teknik Pendinginan Ikan. C.V Paripurna, Jakarta.

Isamu, KT, Hari PS, dan Yuwono S. 2012. Karakteristik Fisik, Kimia dan Organoleptik Ikan Cakalang (Katsuwonus pelamis) Asap di Kendari. Jurnal Teknologi Pertanian 13(2): 105-110.

[KKP] Kementerian Kelautan dan Perikanan 2019. Data BPS diolah Ditjen PDS 2019.

Leha, M. A. 2010. Aplikasi Asap Cair Sebagai Biopresevatif Dalam Bahan Pangan (Ikan Cakalang Asap). Seminar Nasional Basic Science II. ISBN: 978-602-97522-0-5.

Lumi, K, Wagiu, M. 2013. Nilai Ekonomis Sumber daya Perikanan di Sulawesi Utara (Studi kasus Ikan Cakalang, Katsuwonus pelamis). FPIK UNSRAT. Manado. Jurnal IImiah Platax. 1(2): 12-48.

Lindsay, R.C. 1994. Flavoul of Fish. In Shahid, F. and Botta, J.R. (eds). Seafood: Chemistry, Processing Tecnology and Quality. London. Chapman \& Hall. P75-84.

Marasabessy, I. (2007). Produksi asap cair dari limbah pertanian dan penggunaannya dalam pembuatan ikan tongkol (Euthynnus affinis) asap. Tesis. Program Pascasarjana IPB. Bogor.

Mareta DT dan Sofia NA. 2011. Pengemasan Produk Sayuran Dengan Bahan Kemas Plastik Pada Penyimpanan Suhu Ruang dan Suhu Dingin. MEDIAGRO. 7(1). Hal: 26-40.

Moeljanto, 1992. Pengawetan dan Pengolahan Hasil Perikanan, Jakarta: Penebar Swadaya.

Nabila L, Tamrin, dan Isamu K.T. 2017. Karakterisasi Organoleptik, Kimia, dan Mikroba Ikan Kayu Cakalang (Katsuwonus pelamis) dan Ikan Kayu Tongkol (Euthynnus Affinis) Yang Diproduksi Di Kota Kendari. Jurnal Sains dan Teknologi Pangan. 2(3): 530-541.

Nanlohy, Esterlina EEM. 2014. Analisa Total Bakteri pada Ikan Tuna Asap yang direndam dengan Asap Cair "Waa Sagu" selama Penyimpanan
Pada Suhu Kamar. Jurnal Biopendix. Vol 1 (1): 43-4.

Orak H 2006. Total antioxidant activities, phenolics, anthocyanins, polyphenoloxidase activities in red grape varieties. Electronic Journal of Polish Agricultural University Food Science and Technology.9:117-118.

Patty CN, Dotulong V, dan Suwetja IK. 2015. Mutu Ikan Roa (Hemirhamphus Sp.) Asap Yang Ada di Pasar Tradisional di Kota Manado Yang Disimpan Pada Suhu Ruang. Jurnal Media Teknologi Hasil Perikanan. 3(2). Hal: 45-54.

Purnomo H. 1995. Aktivitas Air dan Peranannya dalam pengawetan Pangan. UI Press. Jakarta.

Rahayu, W, P, Maamoen S, Suliantari, dan Fardiaz S. 1992. Teknologi Fermentasi Produk Perikanan. Penerbit Pusat Antar Universitas Pangan dan Gizi, Institut Pertanian Bogor, Bogor.

Riansyah, A., Supriadi, A., Nopianti, R. 2013. Pengaruh Perbedaan Suhu dan Waktu Pengeringan Terhadap Karakteristik Ikan Asin Sepat Siam (Trichogaster pectoralis) Dengan Menggunakan Oven. Program Studi Teknologi Hasil Perikanan. Fakultas Pertanian. Universitas Sriwijaya Indralaya Ogan Ilir. 2(1). Salindeho, N. 2017. Karakteristik Fisiko Kimia, Profil Asam Lemak Ikan Cakalang Asap Menggunakan Bahan Pengasap Sabut Kelapa Dan Cangkang Pala. JPHPI. 20(2). Hal: 392-400.

Sagoo S, Board R, Roller S. 2002. Chitosan inhibits growth of spoilage microorganisms in chilled pork products. Journal of Food Microbiology. 19 (2-3): 175-182.

Saparinto, Cahyo. 2010. Usaha Ikan Konsumsi di Lahan 100m2, Jakarta: Penebar Swadaya.

Shabrina NA, Riyadi PH, dan Anggo PD. 2014. Pengaruh Jarak, Suhu, Lama Pengasapan Terhadap Kemunduran Mutu Ikan Bandeng (Chanos Chanos Forks) Asap Selama Penyimpanan Suhu Ruang. 3(3): 68-74.

Soekarno, S.T. 1990. Penilaian Organoleptik. Bhatara Karya Aksara, Jakarta.

Suyitno, 1990. Bahan-Bahan Pengemas. PAU Pangan dan Gizi UGM, Yogyakarta.

Swastawati F, Eko S, Bambang C, Wahyu AT. 2012. Sensory evaluation and chemical characteristics of smoked stingray (Dasyatis blekeery) processed by using two different 
liquid smoke. International Journal of Bioscience, Biochemistry and Bioinformatics. 2(3): 212-216.

Tribowo, A, 1985. Pengaruh Penundaan Waktu Pengesan dan Lama Pengesan Bahan Mentah Terhadap Mutu Ikan Malalugis (Decapterus macrosoma) Asap Yang Disimpan Pada Suhu Kamar. Tesis. Fakultas Perikanan Dan IImu Kelautan. Unsrat. Manado.

Tumonda S, Mewengkang H.W., dan Timbowo S.M. 2017. Kajian Mutu Ikan Cakalang (Katsuwonus Pelamis L) Asap Terhadap Nilai Kadar Air dan pH Selama Penyimpanan. Jurnal Media Teknologi Hasil Perikanan. 5(2). Hal: 158-162.

Wally E, Mentang F, dan Montolalu R.I. 2015. Kajian Mutu Kimiawi Ikan Cakalang (Katsuwonus Pelamis L.) Asap (Fufu) Selama Penyimpanan Suhu Ruang dan Suhu Dingin. Jurnal Media
Teknologi Hasil Perikanan. 3(1). Hal: 7-12

Widiastuti, I.M.2007. Sanitasi dan Mutu Kesegaran Ikan Kosumsi pada Pasar Tradisional Di Kotamadya Palu. Jurnal Agroland. 14 (1):7781 ISSN: 0854-641X.

Wibowo, S. 2000. Industri Pengasapan Ikan. Penebar Swadaya. Jakarta.

Winarno, F.G. 1986. Enzim Pangan dan Gizi. PT. Gramedia Pustaka Utama. Jakarta. 155 halaman.

Winarno, F.G. 2002. Kimia Pangan dan Gizi. Jakarta: Gramedia Pustaka Utama.

, F.G. 2009. Kimia Pangan dan Gizi. Jakarta: Gramedia Pustaka.

Wowiling $\mathrm{F}$, Berhimpon $\mathrm{F}$, Onibala $\mathrm{H}$, and Mentang $\mathrm{F}$. 2015. Kualitas Organoleptik dan Isotermis Sorpsi Air (ISA) Ikan Cakalang (Katsuwonus pelamis L.) Presto Asap Cair. Media Teknologi Hasil Perikanan. 8(1): 14-22. 